\title{
The Effectiveness Of Scientific Approach With Open-Ended Problem Based Learning Worksheet Viewed From Learning Achievement, Creative Thinking Ability, Interest, And Mathematics Self-Efficacy
}

\author{
Lisda Fitriana Masitoh $^{1)}$, Enggar Prasetyawan ${ }^{2)}$ \\ ${ }^{1,2}$ Pamulang University, South Tangerang \\ E-mail: lisda.masitoh@gmail.com
}

\begin{abstract}
This study aimed to describe the effectiveness and differences of scientific approach with open-ended problem based learning worksheet and scientific approach. The population in this study was students of class VII of SMP Negeri 17 Pamulang, South Tangerang. The sample of this study was determined randomly. They were two classes and the results were VII.3 and VII.4. To determine the effectiveness, one sample t-test was used. To discover the difference of effectiveness, MANOVA (Hotteling's Trace) test was used. The results show that (1) Scientific approach with open-ended problem based learning worksheet and scientific approach are effective viewed from learning achievement, creative thinking ability, interests and mathematic self-efficacy (2) There is no difference in effectiveness between scientific approach with open-ended problem based learning worksheet with scientific approach viewed from learning achievement, creative thinking ability, interests and mathematic self-efficacy (3) Scientific approach with open-ended problem based learning worksheet are more effective than scientific approaches viewed from student achievement.
\end{abstract}

Keywords: Creative thinking, interest, open-ended, problem based leraning, selfefficacy

\section{INTRODUCTION}

One of the challenges in education is ensuring the success of the learning process in schools. Goss, Sonnemann \& Griffths (2017) in their researches conclude that one third of teachers are depressed by the challenge of actively involving students in classroom learning. This actually does not have to happen if the teacher masters the right approach to succeed in learning including mathematics learning. The OECD (2016) has conducted an analysis of mathematics learning practices in the classroom and concluded three criteria that must exist in mathematics learning at this time, namely active learning, teacher are able to activate the cognitive of students, and the last is teachers have role as instructors or facilitators. One focus of learning mathematics in activating the cognitive domain is developing students' abilities in solving unusual problems (complex problems) and solving problems not just in one way (OECD, 2016). This ability is called creative thinking ability.

The National Education System Law Number 20 Year 2003 proposes one of the objectives of national education to develop students' creative potential. This means that in addition to being oriented towards learning achievement, education through learning in schools must accommodate students to develop their creative thinking abilities. Creative thinking is one of the main assets for the nation's generation to compete in facing the challenges of the times. This can be developed through learning mathematics. Furthermore, this is in line with the Minister of National Education Regulation No. 58 of 2014 concerning Junior 
High School Curriculum which states that mathematics should be given to all students starting from elementary school. One of them is to equip students with the ability to think creatively.

Creative thinking skills include the ability to find new or unique solutions, provide many answers and find a variety of ways or strategies to solve a problem (Mardia, 2017; Wrigth, 2010; Ali, 2010; Arends \& Kilcher, 2010; McGredor, 2007; Haylock, 1997; Crow \& Crow, 1977). Every student has the potential to have creative thinking skill, what distinguishes it is the extent to which that potential is developed (Wrigth, 2010). Every education system must encourage students to have creative thinking skill (Yeni et al, 2017). The creative thinking skills can be trained and developed through learning with the Problem Based Learning (PBL) approach (Chakrabarty \& Mohamed, 2013; Senocak \& Sozbilir, 2009). Ali, et al (2010) stated that PBL is learning with problem characteristics as a starting point for student learning processes. He furthermore explained that problems that can be used are open-ended problems. PBL syntax that is synthesized with a scientific approach in the 2013 curriculum includes activities preparing students, problem orientation (observing), asking questions, investigating, communicating and evaluating.

PBL is a recommended method in curriculum 2013 that refers to a scientific approach. The results of research by Nuralam and Eliyana (2017) and Erni, Shaleh \& Wahyu (2017) concluded that scientific learning can improve problem-solving skills. Another study conducted by Fahriza and Winda (2016) concluded that there is an influence of problem-based learning integrated in a scientific approach to the level of students' mathematical creative thinking. In the affective domain, research conducted by Soffi (2016) concluded that there were differences in student confidence in the PBL class and in the PBL class with a scientific approach. Morevover, the results of the study by Lisda (2018) showed that students studying in PBL classes increased their mathematical self-efficacy. In addition to the reults of the studies above, Perez \& Ye (2013) and Lunenburg (2011) stated that mathematical self-efficacy is the level of students' selfconfidence in their mathematical abilities. Therefore, mathematical self-efficacy must continue to be improved because it has a strong influence on mathematics achievement (Fast, et, al, 2015).

In order to be able to understand the benefits of learning mathematics in real life, learning process needs to be designed using Student Work Sheets as attractive as possible and made by connecting them with everyday life (Zulyadaini, 2017). A study conducted by Gloria, et al (2018) concluded that the use of discovery learning worksheets can improve students' reasoning abilities. These results show that the use of more specific worksheets has the potential to increase the ability to think creatively, because the ability to think creatively includes the ability to reason (Krulik \& Rudnick, 1995). Based on Petr, Tomas \& Renata's (2011) research, it was concluded that to attract students' interest in learning science, it needs to be supported by the student work sheeets which contain activities that support students to learn. Worksheets must be interactive, 
interesting and bring students to activities that can improve learning achievement, creative thinking skills, students' interests and mathematical self-efficacy. The student work sheet that is intended in this case is a scientific learning one with the characteristics of the Problem Based Learning approach using open-ended questions.

Based on some interviews with a number of junior high school mathematics teachers in Pamulang District, the researcher obtained information that teachers did not yet know what kind of learning could be used to facilitate students in developing creative thinking skills. They use lesson plans and student worksheets that are only oriented towards student learning achievement. From the observations also obtained the fact that teachers more often use the lecture method and give notes on the blackboard even though the school uses the 2013 curriculum. Some teachers use worksheets that only contain practice questions for students to work on. This kind of learning is not in accordance with the characteristics of the curriculum 2913 where students should be the center of learning activities. Such conditions will certainly have impacts on students' low interest and self-efficacy in mathematics.

Based on the preliminary survey, as many as 200 seventh grade junior high school students in Pamulang region were given a creative thinking test of the material they had learned and were asked to fill in the mathematics interest and self-efficacy questionnaire. The results are shown in the following Table 1:

Table 1. Preliminary Survey Result

\begin{tabular}{cccc}
\hline Level & Creative Thinking & Interest & Self-efficacy \\
\hline Excellent & $5.5 \%$ & $3 \%$ & $8 \%$ \\
Good & $8 \%$ & $12.5 \%$ & $12 \%$ \\
Fair & $21 \%$ & $31 \%$ & $26.5 \%$ \\
Poor & $25.5 \%$ & $43.5 \%$ & $38.5 \%$ \\
Bad & $40 \%$ & $10 \%$ & $15 \%$ \\
\hline
\end{tabular}

The survey shows that the current learning conditions are not yet ideal and it need special attention. Considering these problems, learning models and learning media are needed that can help improve creative thinking abilities, interests and mathematical self-efficacy. An open-ended problem based learning combined with scientific learning Student Worksheet can be used as an alternative solution to the problem. Based on the above background, the researcher intends to conduct research to determine the effectiveness of scientific learning aided by open-ended problem based learning Student worksheet and scientific learning in terms of learning achievement, creative thinking abilities, interests and mathematical selfefficacy of junior high school students. The LKS that is implemented is limited to rectangular and triangular flat material. 


\section{RESEARCH METHOD}

This research is a quasi-experimental one. The selection of this type of research is based on the assumption that the classes used as experiments are equivalent. Quasi-experimental design is a research method that has a control group. So in this study there are two groups; the experimental group and the control group. The experimental group in this study was a group using scientific learning aided by open-ended problem based learning work sheet, while the control group used a scientific approach without worksheet. Data collection techniques in this study were questionnaire and test. The population in this study was seventh grade students of State Junior High School 17 Pamulang, South Tangerang. Random sampling technique is used in this research. The samples in this reseacrh were students in grades VII.3 and VII.4 of State Junior High School 17 Pamulang, South Tangerang. Data collection instruments relevant to this study are presented in Table 2

Table 2. Technique and Data Collection Instrument

\begin{tabular}{|c|c|c|c|}
\hline Name of Data & Objective & Technique & Instrument \\
\hline Achievement & $\begin{array}{l}\text { To know data of } \\
\text { student's achievement } \\
\text { before and after } \\
\text { treatment }\end{array}$ & Test & Multiple Choice \\
\hline $\begin{array}{l}\text { The ability to } \\
\text { think creative in } \\
\text { Mathemattics }\end{array}$ & $\begin{array}{l}\text { To know data of } \\
\text { student's creative } \\
\text { thinking skill before and } \\
\text { after treatment }\end{array}$ & Test & Essay \\
\hline Student's Interest & $\begin{array}{l}\text { To describe student's } \\
\text { interest before and after } \\
\text { treatment. }\end{array}$ & Non Test & $\begin{array}{l}\text { Questionnaire } \\
\text { of Student's } \\
\text { interest }\end{array}$ \\
\hline $\begin{array}{l}\text { Self-efficacy in } \\
\text { Mathematics }\end{array}$ & $\begin{array}{l}\text { To know data of studen't } \\
\text { self-efficacy in } \\
\text { Mathematics before and } \\
\text { after the treatment }\end{array}$ & Non Test & $\begin{array}{l}\text { Self-efficacy } \\
\text { questionanaire }\end{array}$ \\
\hline
\end{tabular}

\section{Data Analysis Technique Descriptive Analysis}

Analysis of the data used in this study consisted of two types; descriptive analysis and inferential analysis. The data analyzed are pretest and posttest data on aspects of learning achievement, creative thinking abilities, students' interests and mathematical self-efficacy. Description of the data was done by finding the average value, maximum value, minimum value, standard deviation and completeness of the data obtained. The minimum completeness criteria (Kriteria Ketuntasan Minimal/KKM) set by the school for mathematics 
subject is 70. This KKM is used to determine the percentage of many students who achieve completeness in terms of learning achievement. To determine the criteria for creative thinking abilities, interests and mathematical self-efficacy, a classification based on ideal mean (Mi) and ideal standard deviation ( $\mathrm{Si}$ ) is used. Conversion of total scores into five scale qualitative data refers to the following Table 3 (Azwar, 2015):

Table 3. Conversion of Quantitative to Qualitative Data with a Scale of Five

Mi : ideal mean

\begin{tabular}{cc}
\hline Interval Score & Criteria \\
\hline $\mathrm{X}>\mathrm{Mi}+1,5 \mathrm{Si}$ & Excellent \\
$\mathrm{Mi}+0,5 \mathrm{Si}<\mathrm{X} \leq \mathrm{Mi}+1,5 \mathrm{Si}$ & Good \\
$\mathrm{Mi}-0,5 \mathrm{Si}<\mathrm{X} \leq \mathrm{Mi}+0,5 \mathrm{Si}$ & Fair \\
$\mathrm{Mi}-1,5 \mathrm{Si}<\mathrm{X} \leq \mathrm{Mi}-0,5 \mathrm{Si}$ & Poor \\
$\mathrm{X} \leq \mathrm{Mi}-1,5 \mathrm{Si}$ & Bad \\
\hline
\end{tabular}

$\mathrm{S}_{\mathrm{i}}$ : ideal deviation standard

In which

$\mathrm{M}_{\mathrm{i}}=\frac{1}{2} \mathrm{x}$ (ideal maximum score + ideal minimum score)

$\mathrm{S}_{\mathrm{i}}=\frac{1}{6} \mathrm{x}$ (ideal maximum score - ideal minimum score $)$

\section{Inferential Analysis}

In inferential analysis the data analyzed are pretest and posttest data on learning achievement, creative thinking skills, and student interest and selfefficacy questionnaires. Data testing was carried out including the assumption test, the two-group average vector similarity test, the test of the effectiveness of learning, and the test of differences in the effectiveness of the two learning. MANOVA test was performed to the data before treatment to see whether there was a difference in initial ability between the two classes by using the formula as follows (Stevens, 2009):

In which:

$$
\begin{gathered}
F=\frac{n_{1}+n_{2}-p-1}{\left(n_{1}+n_{2}-2\right) p} T^{2} \text { with } \\
T^{2}=\frac{n_{1} n_{2}}{n_{1}+n_{2}}\left(\bar{y}_{1}-\bar{y}_{2}\right)^{\prime} S^{-1}\left(\bar{y}_{1}-\bar{y}_{2}\right)
\end{gathered}
$$

$T^{2} \quad: T^{2}$ Hotteling's

$n_{1} \quad:$ Subject at the first group

$n_{2} \quad:$ Subject at the second group

$\left(\overline{\mathrm{y}}_{1}-\overline{\mathrm{y}}_{2}\right)$ : mean vektor

$\mathrm{S}^{-1} \quad$ : Invers matrix covarians

$\mathrm{p} \quad$ : number of dependent variable

The decision criteria is that $H_{0}$ is rejected if $F_{\text {count }}>F_{0.05 ; v_{1} ; v_{2}}$ where the degrees of freedom $v_{1}=p$ and $v_{2}=n_{1}+n_{2}-p-1$. Whereas if using SPSS 21 
software for windows the decision criteria is to reject $H_{0}$ if p-value $<0,05$ and accept $H_{0}$ if p-value> 0,05 .

The effectiveness of the learning approach refers to the mastery of student learning. Scientific learning assisted by an open-ended problem based learning worksheet and scientific approach is declared effective in terms of mathematics learning achievement if the average learning achievement value is more than 70. If viewed from the creative thinking skills, learning is effective if the average value of the posttest of student's mathematical creative thinking ability in each class is included in the good category of more than 58. If viewed from the interest in learning mathematics, learning is considered as effective if the average scores of the students' interest questionnaire in each class are included in the high category of more than 67.

Meanwhile, if viewed from the mathematics self-efficacy, learning is considered as effective if the average final score of the mathematics self-efficacy questionnaire in each class is included in the high category of more than 55. One sample test t-test was conducted to find out the effectiveness of the learning approach. The formula is as follows;

Notes:

$$
t=\frac{\bar{x}-\mu_{0}}{\frac{S}{\sqrt{n}}}
$$

$\bar{x} \quad$ : Mean

$\mu_{0}$ : Hypothesized value

$S \quad$ : Sample of deviation standard

$n$ : Sample

The decision criteria is that $H_{0}$ is rejected if the value of $t_{\text {count }}>t_{\text {table }}$ with a significance level $\alpha=0,05$. Whereas for testing using SPSS 21 for windows, the decision criteria is to reject $H_{0}$ if $\frac{p-v a l u e}{2}<0,05$.

After analyzing with the One Sample t-Test, the analysis continued with the Multivariate Two-Group Test. This analysis was conducted to see whether there was a difference in effectiveness between scientific learning aided by openended problem based learning worksheet and a scientific approach in terms of learning achievement, creative thinking skills, interests, and mathematical selfefficacy in students. SPSS program assistance was used to calculate the above hypothesis. If the results of a multivariate test have differences in effectiveness between the two learning approaches, then a further test (post hoc) is conducted to see which learning approach is more effective. The advanced test procedure used was Benferonni. However, if the result of a multivariate test shows no difference in effectiveness between the two learning approaches, further testing is not carried out. 


\section{RESULT AND DISCUSSION}

There were two kinds of data in this study; data before and after treatment. Data before treatment includes learning achievement pretest, creative thinking ability pretest, learning interest questionnaire pretest, and student mathematics self-efficacy questionnaire pretest, whereas the post treatment data contains posttest learning achievement, posttest creative thinking ability, posttest learning interest questionnaire, and posttest self questionnaire -Efficacy of student in mathematics. Following is a description of each data before and after treatment.

\section{Learning Achievement in Mathematics}

Data of before and after treatment of learning achievement in Mathematics in the two experimental classes is presented in the following table

Table 4. Result of Learning Achievement in Mathematics

\begin{tabular}{|c|c|c|c|c|}
\hline \multirow[t]{2}{*}{ Description } & \multicolumn{2}{|c|}{$\begin{array}{c}\text { Experiment Group } \\
\text { (Open-ended worksheet - } \\
\text { PBL) }\end{array}$} & \multicolumn{2}{|c|}{$\begin{array}{l}\text { Control Group } \\
\text { (Scientific) }\end{array}$} \\
\hline & Pretest & Posttest & Pretest & Posttest \\
\hline Mean & 50,17 & 76,75 & 52,22 & 73,16 \\
\hline Deviation Standard & 9,33 & 6,28 & 7,89 & 7,13 \\
\hline Ideal maximum score & 100 & 100 & 100 & 100 \\
\hline Ideal minimum score & 0 & 0 & 0 & 0 \\
\hline Maximum score & 67 & 90 & 67 & 87 \\
\hline Minimum Score & 33 & 60 & 33 & 60 \\
\hline Completeness (\%) & $0 \%$ & $92 \%$ & $0 \%$ & $79 \%$ \\
\hline
\end{tabular}

Based on Table 4 above, the average score of students' mathematics learning achievement has increased both from research subjects who received treatment using scientific learning assisted by open-ended problem based learning worksheet and using a scientific approach. The average score of mathematics learning achievement tests for scientific classes assisted by the open-ended problem based learning worksheet increased from 50,17 to 76,75 meaning there was an increase of 26,58. For the scientific class, the average score of the mathematics learning achievement test from the pretest was 52,22 to 73,16 at the posttest. It means that it increased by 20,94 . For the percentage of completeness, scientific classes assisted by open-ended problem based learning worksheet reached $92 \%$ or 36 out of 39 students. While the scientific class percentage of completeness by $79 \%$ as many as 31 of 39 students. Judging from the increase in the average sccore of learning achievement, it appears that the treatment using scientific learning assisted by open-ended problem based learning worksheets gives a better impact on students' mathematics learning achievement.

\section{Creative Thinking Skills}

The description of the results of creative thinking skills test by the two classes is presented in Table 5. 
Table 5. Results of Creative Thinking Skill

\begin{tabular}{|c|c|c|c|c|}
\hline \multirow[t]{2}{*}{ Description } & \multicolumn{2}{|c|}{$\begin{array}{c}\text { Experiment Group } \\
\text { (Open-ended worksheet } \\
\text { - PBL) }\end{array}$} & \multicolumn{2}{|c|}{$\begin{array}{l}\text { Control Group } \\
\text { (Scientific) }\end{array}$} \\
\hline & Pretest & Posttest & Pretest & Posttest \\
\hline Mean & 38,94 & 70,19 & 41,03 & 67,95 \\
\hline Criteria & Poor & Good & Poor & Good \\
\hline Deviation Standard & 12,46 & 13,02 & 12,97 & 9,74 \\
\hline Ideal maximum score & 100 & 100 & 100 & 100 \\
\hline Ideal minimum score & 0 & 0 & 0 & 0 \\
\hline Maximum score & 69 & 94 & 69 & 88 \\
\hline Minimum score & 13 & 44 & 13 & 50 \\
\hline
\end{tabular}

Based on Table 5 above, the average score of students' mathematical creative thinking abilities has increased both from the class treated using scientific learning assisted by open-ended problem based learning worksheet and classes using a scientific approach. The average score of mathematics creative thinking ability test for scientific class assisted by open-ended problem based learning worksheet increased from 38,94 (poor) to 70,19 (good). It means that there was an increase of 31,25 . For the scientific class, the average score of the tests of creative thinking ability in mathematics from the pretest was 41,03 (poor) to 67,95 (good) at the posttest. This means it increased by 26,92 .

The frequency distribution of students' mathematical creative thinking abilities in the two experimental classes can be seen in Table 6 below.

Table 6. Frequency Distribution of Creative Thinking Skills

\begin{tabular}{cccccccccc}
\hline \multirow{2}{*}{ Interval Score } & & \multicolumn{3}{c}{$\begin{array}{c}\text { Experiment Group (Open- } \\
\text { ended worksheet - PBL) }\end{array}$} & \multicolumn{4}{c}{ Control Group } \\
& Criteria & (Scientific) & \multicolumn{2}{c}{ Prest } \\
\cline { 3 - 10 } & & Pretest & \multicolumn{2}{c}{ Posttest } & \multicolumn{2}{c}{ Pretest } & \multicolumn{2}{c}{ Posttest } \\
& & f & $\%$ & f & $\%$ & f & $\%$ & F & $\%$ \\
\hline $\mathrm{X}>75$ & Excellent & 0 & $0 \%$ & 12 & $31 \%$ & 0 & $0 \%$ & 5 & $13 \%$ \\
$58<\mathrm{X} \leq 75$ & Good & 1 & $3 \%$ & 18 & $46 \%$ & 2 & $5 \%$ & 26 & $67 \%$ \\
$42<\mathrm{X} \leq 58$ & Fair & 17 & $44 \%$ & 9 & $23 \%$ & 21 & $54 \%$ & 8 & $21 \%$ \\
$25<\mathrm{X} \leq 42$ & Poor & 12 & $31 \%$ & 0 & $0 \%$ & 9 & $23 \%$ & 0 & $0 \%$ \\
$\mathrm{X} \leq 25$ & Bad & 9 & $23 \%$ & 0 & $0 \%$ & 7 & $18 \%$ & 0 & $0 \%$ \\
\hline
\end{tabular}

Based on Table 6 above, the experimental class shows that before being treated there were no students who had excellent creative thinking criteria and only 1 person had good ability criteria. Then after being treated with scientific learning assisted by open-ended problem based learning worksheet, it can be seen that as many as 12 students or $31 \%$ have very good creative thinking criteria that did not exist before. Students on good criteria as many as 18 or $46 \%$ were previously only 1 , students on the criteria are quite good as many as 9 students or $23 \%$, and there are no students who are in the criteria of poor or very poor. 
While in the scientific class it was seen that before being treated there were no students who had excellent creative thinking criteria and 2 students or $5 \%$ were in good criteria. Then after being treated using a scientific approach it can be seen that as many as 5 students or $13 \%$ have very good creative thinking criteria, 26 students or $67 \%$ are in good criteria, 8 students or $21 \%$ are in good enough criteria, and there are no students which is in the criteria poor or bad.

\section{Student's Interest in Mathematics}

The following is a description of the results of the mathematics interest questionnaire by the two experimental classes, both those who were treated with a scientific approach assisted by the open-ended problem based learning worksheet and the scientific approach presented in Table 7 below.

Table 7. Result of Student's Interest in Mathematics Questionnaire

\begin{tabular}{|c|c|c|c|c|}
\hline \multirow[t]{2}{*}{ Description } & \multicolumn{2}{|c|}{$\begin{array}{c}\text { Experiment Group } \\
\text { (Open-ended worksheet } \\
\text { - PBL) }\end{array}$} & \multicolumn{2}{|c|}{$\begin{array}{c}\text { Control Group } \\
\text { (Scientific) }\end{array}$} \\
\hline & Pretest & Posttest & Pretest & Posttest \\
\hline Mean Score & 57,44 & 71,41 & 59,56 & 70,23 \\
\hline Criteria & Average & High & Average & High \\
\hline Deviation Standard & 6,33 & 8,19 & 6,79 & 7,46 \\
\hline Ideal maximum score & 100 & 100 & 100 & 100 \\
\hline Ideal minimum score & 20 & 20 & 20 & 20 \\
\hline Maximum score & 77 & 92 & 75 & 89 \\
\hline Minimum score & 41 & 55 & 45 & 57 \\
\hline
\end{tabular}

Based on Table 7 above, the average score of students' interest in learning mathematics has increased, both from the class who received a scientific approach treated with open-ended problem based learning worksheet and a scientific approach. The average score of interest in learning mathematics for scientific classes assisted by open-ended problem based learning worksheet from pretest to posttest experienced an increase of 13,97. For the scientific class, the average score of mathematics interest from pretest to posttest increased by 10,67. Without using statistical analysis, seen from the difference in the increase in the average score of interest in learning mathematics, it can be seen that the treatment using scientific assisted by open-ended problem based learning worksheet gives a better impact than the scientific approach.

The frequency distribution of students' interests in the two experimental classes can be seen in Table 8 below. 
Table 8. Student Interest Frequency Distribution

\begin{tabular}{|c|c|c|c|c|c|c|c|c|c|}
\hline \multirow{3}{*}{$\begin{array}{l}\text { Interval } \\
\text { Score }\end{array}$} & \multirow{3}{*}{ Criteria } & \multicolumn{4}{|c|}{$\begin{array}{l}\text { Experiment Group (Open- } \\
\text { ended worksheet - PBL) }\end{array}$} & \multicolumn{4}{|c|}{$\begin{array}{l}\text { Control Group } \\
\text { (Scientific) }\end{array}$} \\
\hline & & \multicolumn{2}{|c|}{ Pretest } & \multicolumn{2}{|c|}{ Posttest } & \multicolumn{2}{|c|}{ Pretest } & \multicolumn{2}{|c|}{ Posttest } \\
\hline & & $\mathrm{F}$ & $\%$ & $\mathrm{~F}$ & $\%$ & $\mathrm{f}$ & $\%$ & $\mathrm{~F}$ & $\%$ \\
\hline$X>80$ & Very high & 0 & $0 \%$ & 8 & $21 \%$ & 0 & $0 \%$ & 3 & $8 \%$ \\
\hline $67<X \leq 80$ & High & 2 & $5 \%$ & 18 & $46 \%$ & 4 & $10 \%$ & 23 & $59 \%$ \\
\hline $53<X \leq 67$ & Average & 29 & $74 \%$ & 13 & $33 \%$ & 28 & $72 \%$ & 13 & $33 \%$ \\
\hline $40<X \leq 53$ & Low & 8 & $21 \%$ & 0 & $0 \%$ & 7 & $18 \%$ & 0 & $0 \%$ \\
\hline$X \leq 40$ & Very low & 0 & $0 \%$ & 0 & $0 \%$ & 0 & $0 \%$ & 0 & $0 \%$ \\
\hline
\end{tabular}

Based on Table 8 above, in a scientific class with open-ended problem based learning worksheet can be seen that before being treated there were no students who had very high interests and students who had high interest were only 2 students. Then after being given treatment with scientific learning aided by openended problem based learning worksheet can be seen that as many as 8 students or $21 \%$ have very high interests which were previously 0 , students with high interest as many as 18 or $46 \%$, students with moderate interest as many as 12 students or $33 \%$, and there are no students who have low interests. While in the scientific class, it was seen that when before being given treatment there were no students who had very high requests. Then after being treated using a scientific approach it can be seen that as many as 3 students or $8 \%$ have very high interest, 23 students or $59 \%$ have high interest, 13 students or $59 \%$ have moderate interest, and there are no students who have low or very low interest.

\section{Mathematical Self-efficacy}

The following is a description of the results of mathematical selfefficacy by the two experimental classes, both those who were treated with a scientific approach assisted by open-ended problem based learning worksheet and the scientific approach presented in Table 9 below.

Tabel 91. Result of Mathematical Self-efficacy Questionnaire

\begin{tabular}{|c|c|c|c|c|}
\hline \multirow[t]{2}{*}{ Description } & \multicolumn{2}{|c|}{$\begin{array}{c}\text { Experiment Group } \\
\text { (Open-ended worksheet } \\
\text { - PBL }\end{array}$} & \multicolumn{2}{|c|}{$\begin{array}{l}\text { Control Group } \\
\text { (Scientific) }\end{array}$} \\
\hline & Pretest & Posttest & Pretest & Posttest \\
\hline Mean score & 44,95 & 57,87 & 43,92 & 57,49 \\
\hline Criteria & Low & High & Low & High \\
\hline Deviation Standard & 4,98 & 5,48 & 3,91 & 7,27 \\
\hline Ideal maximum score & 80 & 80 & 80 & 80 \\
\hline Ideal minimum score & 20 & 20 & 20 & 20 \\
\hline Maximum score & 57 & 69 & 51 & 77 \\
\hline Minimum score & 37 & 44 & 35 & 41 \\
\hline
\end{tabular}


Based on Table 9 above, the average score of students' mathematical self-efficacy has increased, both from the class that was treated with a scientific approach assisted by open-ended problem based learning worksheet and a scientific approach. The average score of mathematical self-efficacy for scientific classes assisted by open-ended problem based learning worksheet from pretest to posttest increased by 12,92 . For the scientific class, the average score of mathematics interest from pretest to posttest increased by 13,56. It can be seen that the treatment using scientific aided by Open-ended Problem Based Learning worksheet has a better impact than the scientific approach.

The frequency distribution of students' interests in the two experimental classes can be seen in Table 10 below.

Table 10. Frequency Distribution of Mathematical Self-efficacy

\begin{tabular}{|c|c|c|c|c|c|c|c|c|c|}
\hline \multirow{3}{*}{ Interval Score } & \multirow{3}{*}{ Criteria } & \multicolumn{4}{|c|}{$\begin{array}{l}\text { Experiment Group (Open- } \\
\text { ended worksheet - PBL }\end{array}$} & \multicolumn{4}{|c|}{$\begin{array}{l}\text { Control Group } \\
\text { (Scientific) }\end{array}$} \\
\hline & & \multicolumn{2}{|c|}{ Pretest } & \multicolumn{2}{|c|}{ Posttest } & \multicolumn{2}{|c|}{ Pretest } & \multicolumn{2}{|c|}{ Posttest } \\
\hline & & $\mathrm{f}$ & $\%$ & $\mathrm{f}$ & $\%$ & $\mathrm{f}$ & $\%$ & $\mathrm{~F}$ & $\%$ \\
\hline$X>65$ & Very High & 0 & $0 \%$ & 1 & $3 \%$ & 0 & $0 \%$ & 4 & $10 \%$ \\
\hline $55<X \leq 65$ & High & 1 & $3 \%$ & 29 & $74 \%$ & 0 & $0 \%$ & 20 & $51 \%$ \\
\hline $45<X \leq 55$ & Average & 16 & $41 \%$ & 7 & $18 \%$ & 14 & $36 \%$ & 13 & $33 \%$ \\
\hline $35<X \leq 45$ & Low & 22 & $56 \%$ & 2 & $5 \%$ & 24 & $62 \%$ & 2 & $5 \%$ \\
\hline$X \leq 35$ & Very Low & 0 & $0 \%$ & 0 & $0 \%$ & 1 & $3 \%$ & 0 & $0 \%$ \\
\hline
\end{tabular}

Based on Table 10 above, both classes of pretest data did not have a single student who had very high self-efficacy. Both classes are dominated by students with low self-efficacy, which is in the scientific learning class assisted by open-ended problem based learning worksheet as many as 22 students or $56 \%$ and in the scientific class as many as 24 students or $62 \%$. Then after being given treatment in scientific classes assisted by Open-ended Problem Based Learning worksheet, it can be seen that as many as 1 student or $3 \%$ have very high selfefficacy, as many as 29 or $74 \%$, students have high self-efficacy, 7 students or $18 \%$ are moderate and 2 students or $5 \%$ with low self-efficacy. While in the scientific class, it can be seen that as many as 4 students or $10 \%$ have very high self-efficacy, 20 students or $51 \%$ have high self-efficacy, 13 students or $33 \%$ moderate self-efficacy, and 2 students or $5 \%$ self-efficacy low efficacy. Both approaches provide a basis for increasing students' mathematical self-efficacy.

\section{Test of effectiveness}

Before the effectiveness test is performed, the prerequisite tests namely homogeneity and normality have been fulfilled. The initial conclusions of the two classes are known to perform effectiveness tests.

Table 11. Average Vector Similarity Test Results

\begin{tabular}{cccc}
\hline Effect & Value & F & Sig. \\
\hline Hotelling's Trace & 0,059 & $1,083 \mathrm{~b}$ & 0,371 \\
\hline
\end{tabular}


Based on Table 10 above, the $F$ value is 1083 and the significance value is 0.371 . With a significance value of $0.371>\alpha=0.05$, this shows that Ho is accepted, so it can be concluded that there is no difference in the average pretest score of learning achievement, creative thinking ability, interest and self-efficacy of students' mathematics in the learning group using open-ended problem based learning worksheet and scientific approach. In other words, the initial conditions or initial abilities of the experimental class and the control class are relatively the same.

After treatment with two different approaches, both classes using a scientific approach assisted by open-ended problem based learning worksheet and a scientific approach is carried out hypothesis testing to determine its effectiveness.

Table 12. Normality Test Results

\begin{tabular}{llr}
\hline \multicolumn{1}{c}{ Groups } & \multicolumn{1}{c}{ Variable } & Sig. \\
\hline \multirow{2}{*}{$\begin{array}{l}\text { Scientific approach assisted by } \\
\text { open-ended problem based }\end{array}$} & Learning achievement & 0,153 \\
learning worksheet & Student's interest & 0,193 \\
& Self-efficacy & 0,368 \\
& Learning achievement & 0,074 \\
\hline \multirow{2}{*}{ Scientific Approach } & Creative Thinking Skill & 0,082 \\
& Student's interest & 0,074 \\
& Self-efficacy & 0,896 \\
\hline
\end{tabular}

Based on Table 12 above, information is obtained that the significance score of the Shapiro-Wilk test obtained for data on learning achievement, creative thinking skills, interests and mathematical self-efficacy in both classes is greater than 0,05 which means that the assumption of univariate normality is met for the data after treatment. Then, to see the effectiveness of the two approaches, a one sample t-test was used. Following are the results of the one sample t-test with the help of SPSS:

Table 13 Scientific approaches assisted by Open-ended Problem Based Learning worksheet and scientific approaches

\begin{tabular}{llccc}
\hline \multicolumn{1}{c}{ Groups } & \multicolumn{1}{c}{ Variable } & t & df & Sig. \\
\hline \multirow{2}{*}{$\begin{array}{l}\text { Scientific approach } \\
\text { assisted by open-ended }\end{array}$} & $\begin{array}{l}\text { Learning } \\
\text { Achievement }\end{array}$ & 6,656 & 38 & 0,000 \\
problem based learning & $\begin{array}{l}\text { Creative thinking } \\
\text { skill }\end{array}$ & 5,890 & 38 & 0,000 \\
& $\begin{array}{l}\text { Student's Interest } \\
\text { Self-efficacy }\end{array}$ & 2,611 & 38 & 0,013 \\
\hline \multirow{2}{*}{ Scientific Approach } & $\begin{array}{l}\text { Learning } \\
\text { Achievement }\end{array}$ & 2,704 & 38 & 0,002 \\
\hline & Creative thinking & 6,436 & 38 & 0,010 \\
& & & & \\
\hline
\end{tabular}




\begin{tabular}{llll} 
skill & & & \\
Student's Interest & 2,706 & 38 & 0,010 \\
Self-efficacy & 2,136 & 38 & 0,039 \\
\hline
\end{tabular}

Based on Table 13 above, after being treated using a scientific approach assisted by open-ended problem based learning worksheet, all the significance score of the posttest data of learning achievement, creative thinking ability, interest and self-efficacy is $\langle\alpha=0,05$. It can be concluded that the scientific approach based on open-ended problem based learning worksheet is effective in terms of student achievement, creative thinking ability, mathematical interest and self-efficacy. Similarly, in the classroom with a scientific approach all the significance score of learning achievement, creative thinking ability, interest and self-efficacy data posttest creative thinking ability is $\langle\alpha=0,05$. Thus it can be concluded that the scientific approach is also effective in terms of learning achievement, creative thinking abilities, interests and also the mathematical selfefficacy of students.

Because both approaches are effective, a MANOVA two-group test is performed to determine differences in the effectiveness of the two approaches. The results of differences in the test of the effectiveness of the scientific approach based on open-ended problem based learning worksheet and scientific approach can be seen in Table 14 below.

Tabel 14. Result of effectiveness Approach test of Contextual Teaching and Learning (CTL) with Discovery Approach

\begin{tabular}{cccc}
\hline Effect & Value & F & Sig. \\
\hline Hotelling's Trace & 0,147 & $2,674^{\text {a }}$ & 0,038 \\
\hline
\end{tabular}

Based on Table 14 above, it shows that the $\mathrm{F}$ value is 2,674 and the significance value is 0,038 . With a significance value of $0,038<\alpha=0,05$, this shows that Ho is rejected, so it can be concluded that there is a difference in effectiveness between the scientific approach assisted by open-ended problem based learning worksheet and the scientific approach in terms of learning achievement, creative thinking abilities, interests and self- student mathematical efficacy. Because of the multivariate test results, there are differences in effectiveness between the two learning approaches, then a further test (post hoc) is conducted to see which learning approach is more effective. The advanced test procedure used was Benferonni.

Tabel 15. Result of Benferonni Test

\begin{tabular}{ccc}
\hline Aspect & F & Sig \\
\hline Achievement & 5,536 & 0,021 \\
Creative & 0,727 & 0,397 \\
Interest & 0,442 & 0,508 \\
Self-efficacy & 0,070 & 0,798 \\
\hline
\end{tabular}

Based on the results in Table 15 above, a significant score which is smaller than $0,05 / 2$ is only on the variable of learning achievement, which is $0,021<0,025$, so that Ho is rejected. This shows that the scientific approach 
based on open-ended problem based learning worksheet is more effective than the scientific approach. As for the other variables namely creative thinking, mathematical interest and self-efficacy are equally effective.

The effectiveness of these two learning approaches is because scientific learning is not designed so that the teacher becomes the center of learning activities. It is is designed so that students who are the center of learning activities can actively build their own knowledge. In this case, the teacher acts as a facilitator who monitors student learning activities and gives direction to students in participating in learning. Learning begins when students are truly ready to participate in learning. Before entering into the core learning activities, the teacher facilitates students to recall the prerequisite materials to be used and motivates students to learn. The ability to think creatively can be improved through problem solving activities that require students to think creatively in both scientific and scientific learning with the help of open-ended problem based learning worksheets.

Through the problems given, students begin to get used to thinking creatively by asking questions related to problems. Questions asked by students will be the basis for students to learn the material. The next activity for students is to solve problems through investigation and discussion. In discussion activities, students give ideas and respond to ideas that arise to find solutions to problems. Students are constantly accustomed to solving problems, especially open problems that can train students' creative thinking abilities. After students get a solution to the problem, they must present the results obtained for other friends to respond. The presentation stage can increase students' confidence in their ability to solve problems and tasks related to mathematics. They believe that they have been able to solve mathematical problems that have been given well and can be held accountable.

In the end, when students are able to solve math problems given in each learning activity, students become more confident in their mathematical abilities. Students are increasingly confident in their ability to be able to solve various problems and tasks related to mathematics. Students are also more confident because they are accustomed to conveying their ideas or opinions in group discussion or presentation activities. Scientific learning that is well managed by the teacher will be able to improve both cognitive and affective students which in this case is the interest and self-efficacy of mathematics student. Another finding in this study is that observers see scientific classes with open-ended problem based learning worksheets more active in learning. They are more active in discussing and asking friends or teachers. This finding cannot be used to improve conclusions because there are no valid measuring instruments. Researchers will conduct further research to see the effectiveness of worksheets in terms of student learning activities. 


\section{CONCLUSION AND SUGGESTION Conclusion}

Based on the results of data analysis and discussion that has been described, it can be concluded as follows: (1) Scientific approach with open-ended problem based learning worksheet is effective in terms of learning achievement, creative thinking abilities, interests and mathematical self-efficacy; (2) Scientific approach is effectve in terms of learning achievement, creative thinking abilities, interests and mathematical self-efficacy; (3) There is no difference in effectiveness between the scientific approach and the open-ended problem based learning worksheet with the scientific approach in terms of creative thinking abilities, interests and mathematical self-efficacy; (4) The scientific approach with open-ended problem based learning worksheet is more effective than the scientific approach in terms of student achievement.

\section{Suggestion}

Teachers are advised to use a scientific approach, especially with the help of open-ended problem based learning worksheets because it has been proven effective in terms of learning achievement, creative thinking skills, students' interests and mathematical self-efficacy. Teachers can try to apply a scientific approach including by using open-ended problem based learning worksheets on other material besides flat build material to find out its effectiveness. Applying appropriate positive learning is student-centered learning so that it is appropriate to be an alternative choice of learning approach that is appropriate in the 2013 curriculum.

\section{REFERENCES}

Ali, R., et al. (2010). Effect of using problem solving method in teaching mathematics on the achievement of mathematics students. Asian Social Science, 6 (2), 66-72.

Ali, M. (2010). Mengukur kemampuan berpikir kreatif matematis. Dipresentasikan dalam Konferensi Nasional Matematika XV. Manado: UNIMA.

Arends, R. I., \& Kilcher, A. (2010). Teaching for student learning: Becoming an accomplished teacher. New York, NY: Taylor \& Francis Group.

Azwar, S. (2015). Tes prestasi. Yogyakarta: Pustaka Pelajar.

Chakrabarty, S., \& Muhamed, N. (2013). Problem based learning: Cultural diverse students' engagement, learning and contextualized problem solving in a mathematics class. Wcik E-Journal of Integration Knowledge, 38-49.

Crow, L. D., \& Crow, A. (1977). Psikologi pendidikan. (Terjemahan Drs. Z. Kasijan). New York, NY: American Book Company. (buku asli diterbitkan tahun 1954).

Erny., Shaleh, H. \& Wahyu, W. (2017). Pengaruh Pendekatan Saintifik Pada Pembelajaran Matematika Terhadap Kemampuan Pemecahan Masalah Dan Kemampuan Berpikir Tingkat Tinggi Siswa Kelas X IPA SMA Negeri 1 Kepahiang. Jurnal Pendidikan Matematika Raflesia, 2 (1), 12-38. 
Fahriza, N \& Winda, A. (2016). Hasil Belajar Matematika Dan Tingkat Berpikir Kreatif Siswa SMP Dalam Pembelajaran Berbasis Masalah Yang Terintegrasi Pendekatan Saintifik. Math Didactic: Jurnal Pendidikan Matematika, 2 (3), 171-181.

Fast, L. A., et. al. (2010). Self-efficacy and standardized test performance. Diakses tanggal 22 April 2019 dari http://rap.ucr.edu/efficacy.pdf.

Glory., et al. (2018). The Effect of Students' Worksheet in the Model of Discovery Learning Against the Students' Ability of Reasoning and Mathematical Communication in the Faculty of Mathematics and Natural Science of State University of Medan. International Journal of Sciences: Basic and Applied Research, 37 (3), 70-82.

Goss, P., Sonnemann, J., and Griffiths, K. (2017). Engaging students: Creating Classrooms That Improve Learning. Grattan Institute

Haylock, D. (1997). Recognizing mathematical creativity in school children. Zentralblattfur Didaktik der Mathematics, 29 (3), 68-74.

Ibrahim, B.,Edral,S \& Mustafa, S. (2009). The Effects of Problem-Based Learning Instruction on University Students' Performance of Conceptual and Quantitative Problems in Gas Concepts. Eurasia Journal of Mathematics, Science and Technology Education, 5(2),153-164.

Krulik, S \& Rudnick, J.A (1995). The new sourcebook for teaching reasoning and problem solving in elementary school. Massachusetts: Allyn \& Bacon A Simon \& Schuster Company.

Lisda, F. M. (2018). Improving students' mathematics self-efficacy through problem based learning. Malikussaleh Journal of Mathematics Learning . 1 (1), 23-28.

Lunenburg, F. C. (2011). Self-efficacy in the workplace: impilication for motivation and performance. International Journal of Management, Bussissnes, and Administratio, 14 (1), 1-6.

Mardi,H.R. (2017). Using Discovery Learning to Encourage Creative Thinking. International Journal of Social Sciences \& Educational Studies, 4 (2), 98103.

McGredor, D. (2007). Developing thinking; developing learning: A guide to thinking skills in education. New York, NY: Open University Press

NCTM. (2000). Principles and standards for school mathematics. Reston, VA: The National.

Nuralam \& Eliyana. (2017). Penerapan Pendekatan Saintifik Terhadap Kemampuan Pemecahan Masalah Matematika Di Sman 1 Darul Imarah Aceh Besar. Jurnal Ilmiah Didaktika, 18 (1), 64-76

OECD. (2016). PISA 2016 Teaching Strategies For Instructional Quality. New York: Columbia University

Perez, E. D., \& Ye, Y. (2013). The relationship between mathematics self-efficacy and mathematics achievement of mathayomsuksa students in the english program of st. Joseph bangna school. Assumption Journal, 5(2), 82-92. 
Petr, S., Tomas, M \& Renata, B. (2011). How to increase students' interest in science and technology. Procedia Social and Behavioral Sciences,12, $168-174$

Stevens, J. P. (2009). Applied multivariate statistics for the social sciences fifth edition. New York, NY: Taylor \& Francis Group.

Tatsuoka, M. M. (1971). Multivariate analysis: Techniques for educational and psychological research. New york, NY: John Wiley \& Sons, Inc.

Wrigth, S. (2010). Understanding creativity in early childhood. London: SAGE Publication Ltd.

Yeni., et al. (2017). The Effectiveness of Open-Ended Problems Based AnalyticSynthetic Learning on the Mathematical Creative Thinking Ability of PreService Elementary School Teachers. International Electronic Journal of Mathematics Education, 12 (3), 655-666.

Zulyadaini. (2017). Development of Student Worksheets Based Realistic Mathematics Education (RME). International Journal of Engineering Research and Development, 13 (9), 1-14. 